\title{
Who Asks Most? Institutional Incentives and Referral Activity in the European Union Legal Order
}

\author{
Arthur Dyevre, Angelina Atanasova, Monika Glavina
}

\begin{abstract}
By enabling the Court of Justice to engage and enlist the support of domestic judges, the preliminary ruling mechanism is widely recognized to have played a major role in securing the effectiveness of EU law and in furthering the legal and political integration of the continent. Somewhat less appreciated is the fact that national courts differ significantly in terms of institutional configuration, formal powers and resources and that these disparities can influence the rate at which judges submit references. In this paper, we explore how domestic courts differ in their referral behaviour depending on the position they occupy in the juridical hierarchy (first instance, appellate, supreme) and their subject matter jurisdiction (civil, criminal, administrative, specialised) on the basis of a new dataset extending, complementing and correcting data initially collected by Stone Sweet and Brunell (1998). We find that first instance courts pioneered use of the preliminary ruling procedure, but that appellate and peak courts soon caught up. Following the 2004 enlargement, peak courts have even overtaken lower and intermediate level courts. With respect to subject matter jurisdiction, we find that civil and criminal courts, followed by administrative and tax courts, display the highest referral rates. We interpret these findings as evidence that cross-judicial disparities in referral propensity are influenced by the combined effect of institutional consolidation, organizational design and legal rules.
\end{abstract}




\section{Introduction}

That the preliminary ruling system set up by Article 267 of the Treaty on the Functioning of the European Union has been central to the construction of the European Union legal order is, if anything, a commonplace statement in EU law scholarship. Article 267 has been credited for much of what the CJEU has achievedfrom the landmark cases that paved the way for the constitutionalisation of EU law ${ }^{1}$ to the doctrines that bolstered the economic and social integration of the continent. ${ }^{2}$ So it has been, too, for the cooperation partnership the CJEU has established with national courts. ${ }^{3}$ The procedure has supplied the CJEU with a steady (and rising) stream of cases, without which it would never have become the judicial colossus it now is. But it has also permitted national courts to "mould EU principles to the particularities and sensitivities of their legal systems". ${ }^{4}$

Not surprisingly given the importance of the procedure to the edifice of EU law, an entire cottage industry of Article 267 studies has developed. Straddling the disciplines of law and political science, this literature has variously considered how referral activity vary across time, Member States and echelons of the judiciary. Scholars have sought to explain variations in judicial participation in Article 267 proceedings by pointing to differences in judicial attitudes and educational background $;^{5}$ patterns of transnational economic exchange, ${ }^{6}$ lower court empowerment $;^{7}$ inter-court competition; ${ }^{8}$ legal culture-including litigation rates ${ }^{9}$ - and Member States' noncompliance record. ${ }^{10}$

\footnotetext{
${ }^{1}$ See Van Gend en Loos (Case 26/62) [1963], ECR 13; Costa v. ENEL (Case 6/64) [1964] ECR 585, Simmenthal (Case 106/77) [1978] ECR 629, Francovich and Bonifaci v Italy (Case 6/90) [1991], ECR I-5357

${ }^{2}$ See Cassis de Dijon or Rewe-Zentral AG v Bundesmonopolverwaltung für Branntwein (Case 120/78) [1979] ECR 1805; Bosman Union Royale Belge des Sociétés de Football Association ASBL v Jean-Marc Bosman (Case 415/93) [1995] ECR I-492.1

${ }^{3}$ Walter Mattli \& Anne-Marie Slaughter, Revisiting the European Court of Justice, 52 InT. Organ. 177, 180 (1998); Maarten Vink et al., Explaining the Use of Preliminary References by Domestic Courts in EU Member States: A Mixed-Method Comparative Analysis 2-3 (2009).

${ }^{4}$ Takis Tridimas, Constitutional Review of Member State Action: The Virtues and Vices of an Incomplete Jurisdiction, 9 INT. J. CONST. LAW 737, 755 (2011).

5 Jonathan Golub, The Politics of Judicial Discretion: Rethinking the Interaction between National Courts and the Eurpean Court of Justice, 19 West Eur. Polit. 360 (1996); Karen J. Alter, Establishing the Supremacy of European Law: The Making of AN INTERNATIONAL RULE Of LAW IN EuROPE (Oxford University Press Oxford 2001); Tobias NowaK ET AL., NATIONAL JudGeS AS European Union Judges: Knowledge, Experiences AND AtTitudes of Lower Court Judges in Germany AND the NETHERLANDS (Eleven International Pub 2011).

${ }^{6}$ Alec Stone Sweet \& Thomas L. Brunell, The European Court and the National Courts: A Statistical Analysis of Preliminary References, 1961-95, 5 J. Eur. Public Policy 66 (1998); George Tridimas \& Takis Tridimas, National Courts and the European Court of Justice: A Public Choice Analysis of the Preliminary Reference Procedure, 24 InT. REV. LAW ECON. 125 (2004).

${ }^{7}$ J.H.H. Weiler, A Quiet Revolution: 'The European Court of Justice and Its Interlocutors', 26 ComP. PoLIT. STUD. 510 (1994).

${ }^{8}$ ALTER, supra note 5.

${ }^{9}$ Karen J. Alter \& Jeannette Vargas, Explaining Variation in the Use of European Litigation Strategies: European Community Law and British Gender Equality Policy, 33 Comp. Polit. STud. 452 (2000); Lisa J. Conant, Europeanization and the Courts: Variable Patterns of Adaptation among National Judiciaries, in TrAnsform. Eur. Eur. Domest. Change (Maria Green Cowles et al. eds., Cornell University Press 2001); Marlene Wind et al., The Uneven Legal Push for Europe Questioning Variation When National Courts Go to Europe, 10 EUR. UniOn POLIT. 63 (2009).

${ }^{10}$ Morten Broberg \& Niels Fenger, Preliminary References to the European Court of Justice (OUP Oxford 2014).
} 
With respect to differences among judicial bodies within Member States, some of these studies made claims that were not explicitly grounded in a quantitative assessment of referral rates. This includes the contention, first made by Joseph Weiler, that courts which had not been granted the right to exert constitutional review should be particularly keen to embrace the preliminary ruling system as they had great powers to gain from joining hands with the CJEU. ${ }^{11}$ Unlike Weiler, though, many authors did rely on hard, empirical data to back up their theoretical claims. These more explicitly quantitative studies, however, differed significantly in their geographical and temporal coverage. Some authors looked at referral behaviour in only one or two Member States. ${ }^{12}$ Others, meanwhile, based their analysis on a broader, albeit usually less fine-grained, cross-section of domestic courts. Among the latter was a study conducted by Alec Stone Sweet and Thomas Brunell based on what, at the time, was indubitably the largest data-collection effort ever carried out in the field of EU law. Stone Sweet and Brunell took issue with Karen Alter's Court Competition Hypothesis, which emphasised the differing incentives of domestic courts and characterized lower courts as the "motors of legal integration" through their referrals to the European Court. ${ }^{13}$ Examining referral rates by first instance, intermediate and top courts in the period 1961-1995, they found patterns which seemed inconsistent with the view that lower courts were the most enthusiastic users of the preliminary ruling system:

"[O]ver the entire life of the Community, appellate courts have been more active than lower courts in referring questions to the European Court. If we consider the fact that there are many more lower than appellate courts, and that lower courts process the vast bulk of national litigation, this discrepancy is all the more striking. Because a core function of appellate judging is to resolve disputes involving legal interpretation and conflict of law, we would expect the appellate courts to be far more involved in the construction of the legal system than Alter imagines them to be."14

Since Stone Sweet and Brunell's seminal study, though, no serious attempt has been made to return to the issue to document disparities in referral dynamics across levels of the judiciary in comprehensive fashion. How have these dynamics changed after 1995? How does the courts' position in the judicial pecking order affect their propensity to use the preliminary ruling system in the 16 countries that have joined the EU since then? Moreover, the EU has experienced major institutional and doctrinal developments-some brought about by treaty revisions, others by CJEU rulings - since the mid-1990s. We may reasonably expect them to influence judicial attitudes towards EU law and Article 267.

\footnotetext{
${ }^{11}$ Weiler, supra note 7 , at 2426.

${ }^{12}$ See Alter, supra note 5 (focusing on French and German courts); Conant, supra note 9, at 108 (looking at French, German and UK courts).

${ }^{13}$ Karen J. Alter, The European Court's Political Power, 19 West Eur. Polit. 458, 467 (1996).

${ }^{14}$ Sweet \& Brunell, supra note 6, at 90.
} 
A related question is how, independently of the position occupied in the court hierarchy, variations in subject matter jurisdiction affect preliminary reference activity. Some, like De la Mare ${ }^{15}$ and Broberg and Fenger, ${ }^{16}$ have argued that the more specialised a court is, the keener it will be to write references to Luxembourg. Others have made the opposite claim, contending that greater familiarity with EU law will make specialised courts more confident to solve EU law matters without assistance from the CJEU. ${ }^{17}$ Yet others have insisted that, owing to the narrow base and high access costs of EU law, civil and commercial courts should be the most frequent users of the preliminary reference procedure. ${ }^{18}$ Which hypothesis does the full data support? How has the proportion of references submitted by civil, administrative, constitutional and specialised courts evolved over time and across Member States?

The present paper purports to answer these questions by refining our theoretical understanding of judicial choice making in the context of the preliminary ruling system and by adducing new data to support this theoretical account. We review existing attempts to explain cross-judicial variations in referral rates and set forth a more elaborate conception of the determinants of referral behaviour; one that incorporates insights from management-based theories of judging ${ }^{19}$ and institutional analysis. To substantiate our analysis and assess the empirical plausibility of competing accounts of referral participation, we deploy a new dataset that extends, revises and supplements the data originally collected by Stone Sweet and Brunell. Covering 56 years of preliminary reference activity in all EU-28 Member States, our data documents referral patterns for the different levels of courts as well as for their subject matter jurisdiction. Our analysis shows that first instance courts did pioneer use of the preliminary ruling procedure. These courts, however, have been somewhat volatile in their use of Article 267. Meanwhile, peak courts, and to a lower extent intermediate appellate courts too, have steadily caught up on them. To the point that, following the 2004 enlargement, peak courts have even overtaken lower and intermediate level courts in absolute referral rates. With respect to subject matter jurisdiction, we find that civil and criminal courts, followed by administrative and tax courts, display the highest referral rates. We interpret these findings as evidence that national courts are influenced by the process of institutional consolidation of EU law, but also by legal rules and organizational design, including resource allocation within the judicial hierarchy, when deciding whether to request a preliminary ruling.

\footnotetext{
15 Thomas De la Mare, Article 177 in Social and Political Context, in The Evolution of EU law 215-60, 234 (Paul Craig \& Grainne de Búrca eds., 1999).

${ }^{16}$ BROBERG \& FENGER, supra note 10 , at 56.

${ }^{17}$ BarRy Rodger, ARTICle 234 AND COMPETITION LAW: AN ANALYSis 28 (2008).

${ }^{18}$ Conant, supra note 9.

${ }^{19}$ Lee Epstein et al., The Behavior of Federal Judges: A Theoretical and Empirical Study of Rational Choice (Harvard University Press 2013).
} 
The paper is structured as follows. Section Two discusses the theories of adjudication that have been put forward as explanations for the conduct of national courts by social scientists and legal scholars. Section Three sets out our own, preferred account, which blends various strands of theoretical thought on law and judges. Domestic judges, we argue, are subject to a variety of incentives and constraints that affect their referral behaviour. One potential source of behavioural divergence arises from the demands of caseload management and the resources available to handle it. Another stems from the evolving institutional environment in which national courts operate. The combination of greater resources and a smaller workload means that the opportunity cost of requesting a preliminary ruling are lower for higher courts. At the same time, the institutional consolidation of European law has put greater pressure on peak courts to comply with their obligation under Article 267 TFEU. Next, Section Four presents our data and explains how it supports our theoretical account. We show that courts which long resisted legal integration, like many constitutional courts, have come under heightened pressure to submit references. We conclude, though, with some thoughts on institutional disintegration and the impact of the political crisis that has marred the European project in recent years on national courts.

\section{Debates and Theoretical Perspectives}

\section{The Legal Model}

When seeking to elucidate the conduct of national courts, legal academics typically accord priority to legal factors. ${ }^{20}$ Assuming that judges respond primarily to legal stimuli, one may first point to the plain meaning of Article 267 TFEU as possible driver of behavioural differentiation. As it is well known, Article 267 distinguishes between national courts "against whose decisions there is no judicial remedy under national law" and all the other national courts that do not fit this definition. As to the former, it specifies that, when the interpretation of EU law is material to the case, a preliminary ruling "shall" be requested — which implies an obligation. With regard to latter, by contrast, it says that in such cases a preliminary ruling "may" be requested - which implies discretion. The language of Article 267 must, of course, be considered in light of the CJEU's determinations regarding the obligations of peak courts, most notably the acte clair doctrine first articulated in CILFIT. ${ }^{21}$ The doctrine stipulates that the obligation does not apply where the CJEU's ruling would have no bearing on the final decision in the main proceedings before the national court. Likewise, the obligation does not hold when the CJEU has already ruled on an identical question; has already

${ }^{20}$ See e.g. Monica Claes, The National Courts' Mandate in the European Constitution (Hart 2006).

${ }^{21}$ CILFIT (Case 283/81) [1982] ECR 3415 
provided an interpretation of the same provision of EU law (referred to as acte éclairé); or the interpretation of the EU law provision is so obvious as to leave no reasonable doubt (acte clair). ${ }^{22}$

Taking these doctrinal refinements into account, the legal model suggests that last instance courts should be expected to submit more references than courts lower down the judicial hierarchy.

\section{Judicial Empowerment}

Other theories of judicial motivation in the Article 267 literature were explicitly premised on the notion that judges seek to expand their power. This presumption was certainly central to the Empowerment Hypothesis. As its most famous exponent, Joseph Weiler, put it:

"[N]ormative acceptance of the ECJ constitutional construct and practical utilization through the Article [267] process by national courts may be rooted in plain and simple judicial empowerment. [...] Has not power been the most intoxicating potion in human affairs?"23

Weiler argued that domestic courts which did not hold the power of constitutional review under domestic law would be more inclined to use EU law. This was because through the Court of Justice and Article 267 these courts could acquire the right to set aside parliamentary legislation. A right hitherto inexistent in their legal system or one that had remained the exclusive preserve of specialised, constitutional judges. Of the judicial empowerment that accompanied the integration process Weiler wrote:

"The empowerment was not only, or even primarily, of the European Court of Justice, but of the Member State courts, of lower national courts in particular. Whereas the higher courts acted diffidently at first, the lower courts made wide and enthusiastic use of the Article [267] procedure. This is immediately understandable both on a simple individual psychological level and on a deep institutional plane. Lower courts and their judges were given the facility to engage with the highest jurisdiction in the Community and thus to have de facto judicial review of legislation. For many this would be heady stuff." 24

Insofar as constitutional review existed at all in the countries that joined the European Union, centralised review was the norm. So the empowerment hypothesis suggested that most domestic judges would be keen to request references, at least to the extent that litigants raised EU law questions in the disputes brought

\footnotetext{
22 BROBERG \& FENGER, supra note 10, at 230-36.

${ }^{23}$ Weiler, supra note 7 , at 523.

${ }^{24}$ J. H. H. Weiler, The Transformation of Europe, YALE LAW J. 2403-2483, 2426 (1991).
} 
before them. Yet it implied that constitutional courts would be the least enthusiastic users of the preliminary ruling system, as they had no additional powers to win from EU law. ${ }^{25}$

\section{Court Competition}

Akin, yet distinct from the Empowerment Hypothesis is the court competition hypothesis. The hypothesis was originated by Karen Alter, who saw it as an extension and refinement of Weiler's empowerment narrative. ${ }^{26}$ As its name implies, the court competition hypothesis emphasised rivalry among domestic courts as incentive to use Article 267 and how this gave lower courts greater incentives to submit references. The focus on lower courts was, in itself, hardly new. In his articulation of the empowerment hypothesis, Weiler, too, discussed the position of lower courts. And he, too, saw the procedure as enjoying great popularity among lower courts ${ }^{27}$ - a view echoed in the work of other scholars at the time. ${ }^{28}$ Unlike Alter, however, Weiler did not expressly mention the possibility for lower courts to use the procedure as a means to circumvent their judicial hierarchy. The empowerment narrative, it seemed, was primarily concerned with the preliminary ruling procedure as a means to expand the courts' power against the other branches of government. Alter's argument, by contrast, focused more on dynamics within judiciaries. She contended that lower domestic courts seeking to change the doctrinal status quo could use Article 267 to "appeal" before the CJEU against their higher courts' jurisprudence:

"Lower court judges, with the luxury of focusing only on the case at hand, are usually less concerned with the coherence of the national legal system. In addition, the preliminary ruling mechanism allows lower courts to appeal to an authority outside the national legal system, securing an authoritative counter-precedent to the interpretations of national supreme courts. As long as a lower court agrees with ECJ interpretations, ECJ decisions actually lend legal credibility to a lower court decision and thus bolster the influence of the lower court within the national legal system. As such, references to the ECJ have become a convenient means to circumvent higher courts. The ECJ is like a second parent in a battle where parental permission wards off a potential sanction for misbehaviour - if the lower court does not like what they think one parent (the higher court) will say, they can ask the other parent (the ECJ) to see if they will get a more pleasing answer." ${ }^{29}$

\footnotetext{
${ }^{25}$ Weiler, though, did not explicitly draw out the implications of his argument in terms of constitutional courts vs other courts and generally lumped together administrative supreme courts like the French Conseil d'Etat and constitutional tribunals like the German and Italian constitutional courts, see Weiler, supra note 7, at 521 ..

${ }^{26}$ Alter, supra note 13.

${ }^{27}$ Weiler, supra note 24, at 2426; see also Weiler, supra note 7, at 523 ('typically lower courts have been willing partners in this use of Article [267] against national public authorities').

${ }^{28}$ See Anne-Marie Burley \& Walter Mattli, Europe Before the Court: A Political Theory of Legal Integration, 47 INT. ORGAN. 41, 63 (1993).

${ }^{29}$ Alter, supra note 5, at 48.
} 
Other scholars had already noticed the possibility Article 267 offered to lower domestic courts to rebel against their hierarchy, ${ }^{30}$ but did not go as far as Alter in generalizing this scenario. In any case, she clearly hypothesised that lower courts should, in general, be more willing to use the preliminary ruling mechanism.

\section{Subject Matter Jurisdiction and Litigation Patterns}

Finally, EU judicial scholars have considered how subject matter jurisdiction and litigation dynamics affect referral propensity. De la Mare posited that more specialised national courts would send preliminary references to Luxembourg with greater frequency. ${ }^{31}$ The claim following from the supposition that highly specialised courts use EU law more extensively in their daily work and, therefore, have more reasons, as well as more opportunities, to raise reference. Non-specialised courts, on the other hand, operate across multiple, often heterogeneous legal domains and their experience with EU law is more diffuse. So they are likely to attempt to solve EU law questions on their own, without getting the CJEU involved, when these arise. $^{32}$ Along similar lines, Broberg and Fenger observed that courts specialising in VAT or customs disputes deal almost exclusively with regulations that result from the transposition of EU law into domestic law. Consequently, the cases that reach these courts virtually always involve EU law. On account of their constant exposure to EU law, courts falling in this category are better at spotting EU law issues that may require elaboration from the Court of Justice. ${ }^{33}$

Barry Rodger turned this argument on its head, by suggesting that greater exposure to EU law makes specialised courts more confident to solve questions of EU law on their own. ${ }^{34}$ He pointed to the decrease in preliminary references submitted by French competition courts as evidence that these judges had become more familiar with EU competition law. ${ }^{35}$

In a different vein, Lisa Conant stressed the narrow base and high access costs of EU law litigation to claim that courts dealing with commercial disputes are more likely to raise preliminary references. ${ }^{36}$ The argument entailed that civil and commercial courts would be frequent submitters but administrative courts less so. A similar line of reasoning led Stone Sweet and Brunell to suggest that constitutional and administrative courts would be less likely to pass on references to the Court of Justice. ${ }^{37}$

\footnotetext{
${ }^{30}$ See in the British context Richard Rawlings, The Eurolaw Game: Some Deductions from a Saga, 20 J. LAw SoC. 309,320 (1993) (discussing how lower English courts invoked EU law to challenge entrenched precedents on Sunday trading).

${ }^{31}$ T. de la Mare, Article 177 in Social and Political Context, in Evol. EU LAW 215 (Paul Craig \& Gráinne de Búrca eds., Oxford university press 1999).

32 Broberg \& Fenger, supra note 10, at 55; P.P. Craig \& G. De BúrCa, EU Law: TeXt, Cases, and Materials (Oxford University Press, Sixth edition ed. 2015).

${ }^{33}$ BROBERG \& FENGER, supra note 10, at 56.

${ }^{34} I d$.

${ }^{35}$ RODGER, supra note 17 , at 28.

${ }^{36}$ Conant, supra note 9 , at 109.

${ }^{37}$ Sweet \& Brunell, supra note 6, at 91.
} 


\section{Resource Management and Institutional Consolidation}

To these theories, we add our own account of referral behaviour. We start from the observation that domestic judges, as all public sector workers, have limited resources to process a workload that can be considerable. Judges want to be seen as doing their job well. But they have to process their workload knowing that (1) there are only 365 days in a year and 24 hours in a day; and (2) that they have other interests, needs and personal obligations, which include family, rest and leisure time. ${ }^{38}$ According to Stone Sweet and Brunell, judges "want to dispose of their workload efficiently and to go home at the end of the day knowing that they solved more rather than less work problems." ${ }^{39}$ These preferences and constraints create trade-offs, ${ }^{40}$ which may have a direct bearing on the decision to request a preliminary ruling. The time and effort expended in preparing, drafting and submitting a reference are as much time and effort that cannot be used for something else, such as disposing of cases already on the court's docket or time at home with family and friends. There are, in other words, opportunity costs attached to participation in Article 267 proceedings. Other things being equal, the larger the judge's workload, the larger the opportunity costs. Of course, extra support in the form of law clerks and assistants can lower these costs. Not all domestic judges have access to such resources, though. This warrants the conclusion there are significant variations in resource/caseload ratio and, therefore, considerable differences in the opportunity costs domestic courts attach to the decision to refer.

Now consider the disparities between peak courts and first instance courts in terms of resource/caseload ratio. Thanks to a comparatively larger bench and a comparatively smaller caseload along with the added support of law clerks and secretaries, peak court judges normally enjoy a high resource/caseload ratio. These resources make for smaller opportunity costs. Judges on these courts can be confident that submitting a reference will not eat into precious family time or significantly delay the resolution of cases waiting on the court's docket. First instance judges, on the other hand, rarely enjoy the support of clerks and other non-judicial staff. Nor do they all have access to a state-of-the-art library, online databases, research unit, and so on—all amenities that high court judges are more likely to enjoy. So, for a

\footnotetext{
${ }^{38}$ For judges with a foot in academia, other interests also involves non-judicial work like lecturing and penning the odd law review article. Elliott Ash and Bentley MacLeod argue that the judge's fundamental problem is to allocate time across "inside" and "outside' activities. With "inside' referring to the work-related tasks the judge carries during her working hours and "outside' designating the all the other activities, whether it is leisure, writing books, teaching or any other non-judicial activity. See Elliott Ash \& W. Bentley MacLeod, Intrinsic Motivation in Public Service: Theory and Evidence from State Supreme Courts, $58 \mathrm{~J}$. LAW ECON. 863 (2015).

${ }^{39}$ Sweet \& Brunell, supra note 6 , at 73 .

${ }^{40}$ EPSTEIN ET AL., supra note 19, at 7.
} 
first instance judge, larger opportunity costs may result, practically, in having to choose between writing a preliminary reference and being home on Friday night. ${ }^{41}$

Hence the demands of resource management suggest that, other things being equal, high and intermediate courts should exhibit a higher referral propensity than lower courts. Moreover, we should expect the division of labour within the judiciary to reinforce this dynamic. In broad brushes, the judicial division of labour entails that lower courts focus on dispute resolution whereas higher courts are supposed to concentrate on policymaking to ensure that legal solutions remain coherent across individual rulings. Contrary to what Alter suggested, we believe that the fact that lower court judges focus only on the case at hand rather than on the systemic implications of legal doctrines actually reduces the benefit of cooperating with the CJEU via Article 267. Indeed, the benefit of cooperation in the case of lower courts may only extend to the dispute at hand, while for peak and appellate courts it extends to all disputes with similar fact patterns. With high opportunity costs, the benefit to the parties or to the judge's conception of justice in the dispute at hand will have to be exceptionally high to spur a lower court to request a preliminary ruling. To be sure, because lower courts are so numerous and adjudicate millions of disputes every year, there might be enough exceptional disputes of this kind to account for a good share of a rising stream of references. But this should do little to diminish the fact that, even at the rate of about 150 references a year, a reference will represent an exceedingly rare event—one which most lower court judges will never experience in their entire judicial career.

Somewhat counterintuitively, given what we just said, our theoretical framework is perfectly consistent with the possibility that lower courts will refer more in the early stages of the integration process. This is because of the second building block of our theory, which specifies how the self-reinforcing logic of institutional consolidation should be expected to influence the conduct of higher court judges. ${ }^{42}$

When an international regime is its infancy, as was the European Community in its foundational period, its base of supporters at domestic level will be very limited. In such circumstances, it is possible for a few "accidents" to happen every year, leading one court judge here or there to give collaboration with the new international regime a try. Yet the social pressure to do so is, at this stage in the life of the regime, bound to be extremely low. In the EU, the consequence was that high courts could afford to ignore the plain meaning of Article 267 or to dismiss CJEU doctrines without fear of attracting criticism. The more

\footnotetext{
${ }^{41}$ According to Craig and de Búrca, temporal costs together with financial costs to the parties represent a significant barrier to access to the preliminary ruling system, see The Evolution of EU Law 375 (Paul Craig \& Gráinne de Búrca eds., Oxford University Press, Second Edition ed. 2011).

${ }^{42}$ This part of our analysis draws on the work Douglass C. North, Institutions, Institutional Change AND ECONOMiC PERFORMANCE (Cambridge university press 1990).
} 
Eurosceptic among these courts could even realistically hope to suppress whatever attempts lower courts had made to work with the Court of Justice.

As more litigants, legislators and judges begin to re-coordinate around the new regime, however, there is a point at which such a stance becomes untenable. As more domestic actors come to expect judges to uphold the rules of the international regime, recalcitrant courts find themselves locked-up by the selfreinforcing logic of institutionalization. They are soon faced with a choice between accepting integration and enduring increasing isolation. Pinpointing exactly when the European project reached this tipping point may be difficult. But it seems reasonable to believe that it coincided with the political relaunch of integration in the mid-1980s. By then, it was becoming clear that there was no way high court judges could put the genie back into the bottle. The jurisprudential U-turn of the French Conseil d'Etat, which eventually accepted the supremacy of EU law over posterior legislation in 1989 after decades opposing the doctrine, may well have been induced by this realization. ${ }^{43}$

Once a regime has reached this advanced stage of institutional consolidation, it is only a matter of time for the logic of resource management to develop its full effect. Domestic courts that once felt free to ignore the regime's rules when it suited their agenda will come under growing pressure to observe them. Judges who entertained the hope that they could reverse the integration process will feel that they have little choice but to accept the new normal. The realization that they cannot turn the clock of integration back may even spur them to actively seek cooperating with supranational adjudicators when this serves their interests - “if you can't beat them, join them". As the path-dependent logic of institutionalization unfolds, thus, differences in resource/workload ratio will be increasingly reflected in the courts' conduct. So, as regards the EU legal order, our theory predicts that, over the long run, peak courts will dominate the preliminary ruling system.

In the remainder of the paper we examine the extent to which this and other strands of theory fit the data.

\footnotetext{
${ }^{43}$ See ALTER, supra note 5, at 145-51.
} 


\section{Data and Definitions}

Our dataset builds off from the efforts of Alec Stone Sweet and Thomas Brunell, ${ }^{44}$ whose dataset we extended, revised and supplemented in several ways. First, we collected all the references submitted between 1 January 2007 and 31 December 2015, thereby adding close to three thousand observations to the original dataset. Like Stone Sweet and Brunell, we collected the following information for every reference: filing date, case number, case outcome (order, judgment, pending...), Member State of origin, name of referring court and area of EU law affected. Second, while coding these references, we corrected several mistakes in the original dataset, including many errors in the names of the referring courts. Finally, we added two new variables to the dataset: (1) the position of the referring court in the judicial hierarchy, and (2) the subject matter jurisdiction of the referring court. Most of the information was coded from the CJEU's official website, Curia. ${ }^{45}$ To determine the position of the referring courts in the court system, we further relied on the European Judicial Atlas ${ }^{46}$ and on Juridictions des États membres de l'Union européenne ${ }^{47}$.

Establishing the hierarchical position of a judicial body is not always straightforward. Surprisingly, although much has been written about the alleged differential in referral rates between higher and lower courts, judicial scholars have not provided explicit operationalisations to identify these categories across Member States. Alec Stone Sweet and Thomas Brunell lamented that Karen Alter's research did not offer operational definitions of what she meant by "higher" and "lower" courts. ${ }^{48}$ Their own study divided domestic courts in three groups: (1) lower courts, (2) intermediate courts, and (3) higher courts. ${ }^{49}$ Yet the codebook accompanying their dataset does not specify the criteria used to implement this classification.

Our own classification scheme identify courts according to five categories: (1) first instance; (2) second instance; (3) peak; (4) single instance; and (5) non-judicial. A first instance court we defined as a court with original jurisdiction against whose decisions a judicial remedy exists; an intermediate or second instance court as a court with jurisdiction to hear appeal from first instance courts; a peak court as a court with jurisdiction to review the decisions of intermediate courts; and a single instance court as a court with original jurisdiction but against whose decisions no judicial remedy exists. Because of the occasionally complex juxtaposition of original and appellate jurisdiction, we took the category "peak court" to include

\footnotetext{
${ }^{44}$ Sweet \& Brunell, supra note 6.

${ }^{45}$ Curia [http://curia.europa.eu/juris/recherche.jsf?cid=567920]

${ }^{46}$ European Commission - Judicial Atlas - Home, http://ec.europa.eu/justice_home/judicialatlascivil/html/index_en.htm.

${ }^{47}$ CURIA - Courts of the Member States of the European Union - Court of Justice of the European Union, https://curia.europa.eu/jcms/jcms/Jo2_7231/en/.http://curia.europa.eu/jcms/jcms/Jo2 7231/fr/

${ }^{48}$ Sweet \& Brunell, supra note 6, at 71 ('most unfortunately [...], Alter fails to provide a stable, working definition of coding protocol for what she means by "higher" and opposed to "lower" courts').

${ }^{49} I d$. at 89.
} 
all supreme courts and constitutional courts, even when these exert original jurisdiction. ${ }^{50}$ As for nonjudicial bodies, the category subsumes a varied set of entities, encompassing regulatory bodies, antidiscrimination agencies, data protection watchdogs and advisory commissions. ${ }^{51}$

Most challenging was the development of a meaningful typology for the courts' subject matter jurisdiction. There is a great deal of idiosyncratic, country-specific variations in the way subject matter jurisdiction is demarcated across national judiciaries, depending on the number of branches, hierarchies and degree of specialisation within the domestic court system. Consequently, it is hard to do justice to the diversity and complexity of the arrangements governing the delimitation of jurisdictional boundaries while simultaneously ensuring that conceptual distinctions remain intelligible across all EU-28 Member States. In that sense, there is no perfect classification and any typology is likely to work better for some Member States than for others. Striking a balance between complexity and tractability, our strategy was to start with a relatively fine-grained typology comprising 16 categories. ${ }^{52}$ Many of these categories proved to be highly country-specific (some applying to only one court in one Member State). So, in a second step, we merged these categories to construct more abstract groupings which we tried to make as relevant as possible to the theoretical discussion. Our workhorse, four-item typology distinguishes (1) civil, (2) administrative, (3) constitutional, and (4) others - the classification assumed by many authors. Additionally, we constructed an alternative classification with financial, tax, social, labour, commercial and intellectual property courts grouped together as "specialised" courts, and civil, criminal, family, administrative and commercial courts as "generalist" courts.

\section{Results}

\subsection{The Volatility of Lower Courts and the Steady Rise of Intermediate and Peak Courts}

\footnotetext{
${ }^{50}$ Cases for which the position of the court could not be determined were coded NA - approximately 20 cases.

51 The examples of non-judicial bodies: Skatterattanamnden, Utlänningsnämnden and Mora Kommun in Sweden; Komisia za zashtita ot diskriminatsia in Bulgaria; Úřad průmyslového vlastnictví in Czech Republic; Landesvergabeamt, an independent federal authority, in Austria.

${ }^{52}$ Civil/criminal; Administrative; Courts dealing with constitutional matters; Financial and tax courts; Social; Labour; Social and labour; Commerce; Family law; Arbitration tribunal/court; Intellectual property; Civil/criminal/administrative;

Civil/criminal/fiscal; Civil/criminal/constitutional; Other specialised courts/agencies.
} 
Plotted in Figure 1 is the evolution of referral rates by court level over the lifetime of the EU. The figure shows clearly what led scholars writing in the 1990s to emphasize the role of lower courts in legal integration. In absolute numbers, these courts were the most frequent submitters right until the turn of the millennium. Referral rates for peak and second instance courts, meanwhile, rose steadily. Since the mid2000s peak courts consistently raise more preliminary references than first instance courts. The gap between

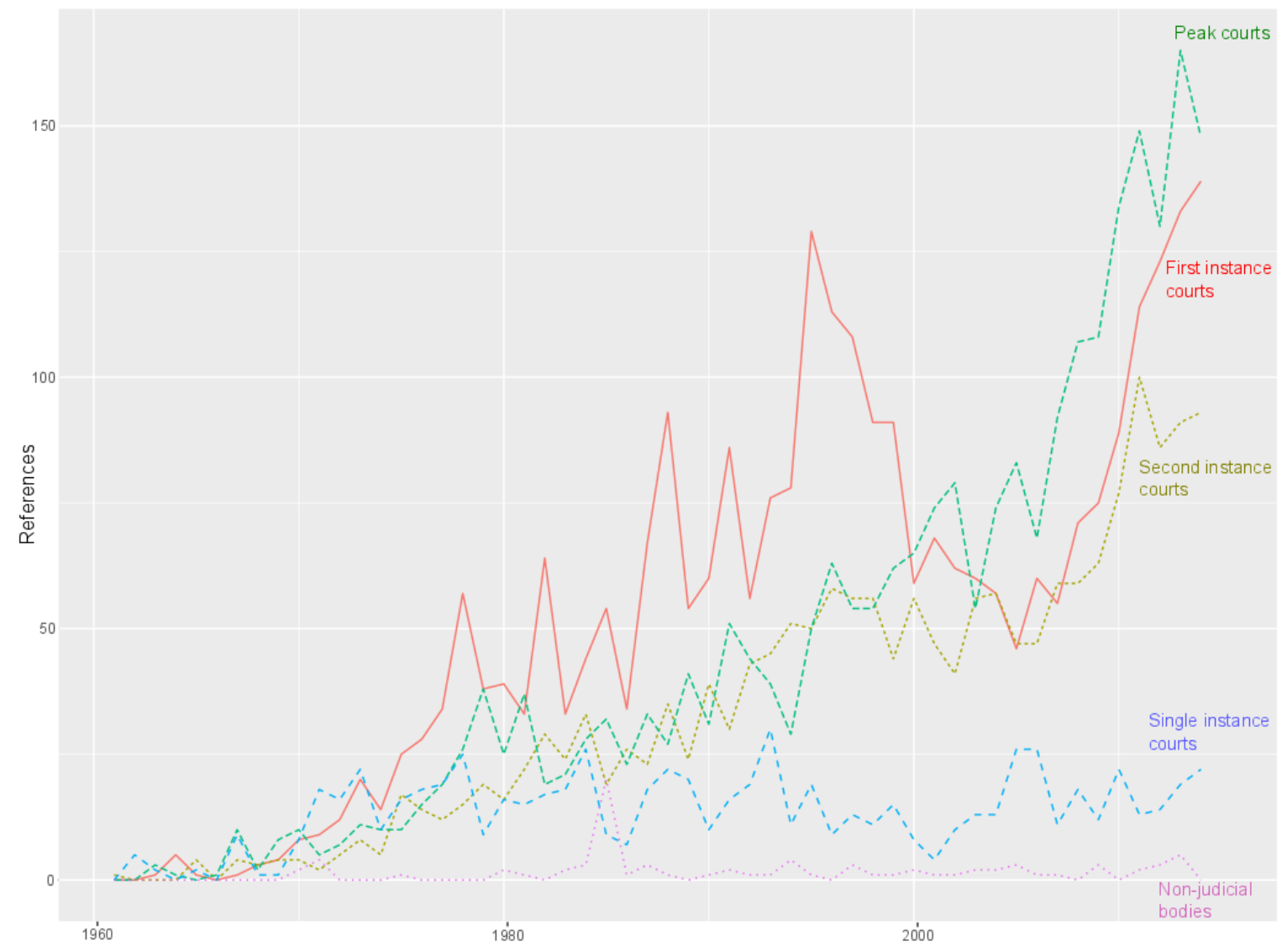

Figure 1. Referral Activity by Court Level, 1961-2014

first instance and intermediate courts has also shrunk. Since the mid-2000s, referral rates for second instance courts often equal those for the courts below them. This evolution looks even more remarkable when we consider that there are thousands of first instance courts, but far fewer appeal courts, and only 65 peak courts in the entire European Union - and not all of them have referred questions to the CJEU. Another noteworthy difference between lower and higher courts is volatility. The curve for first instance courts in Figure 1 reveals lots of marked peaks and valleys, whereas fluctuations around the long term trend are far less pronounced in the case of peak and second instance courts. 


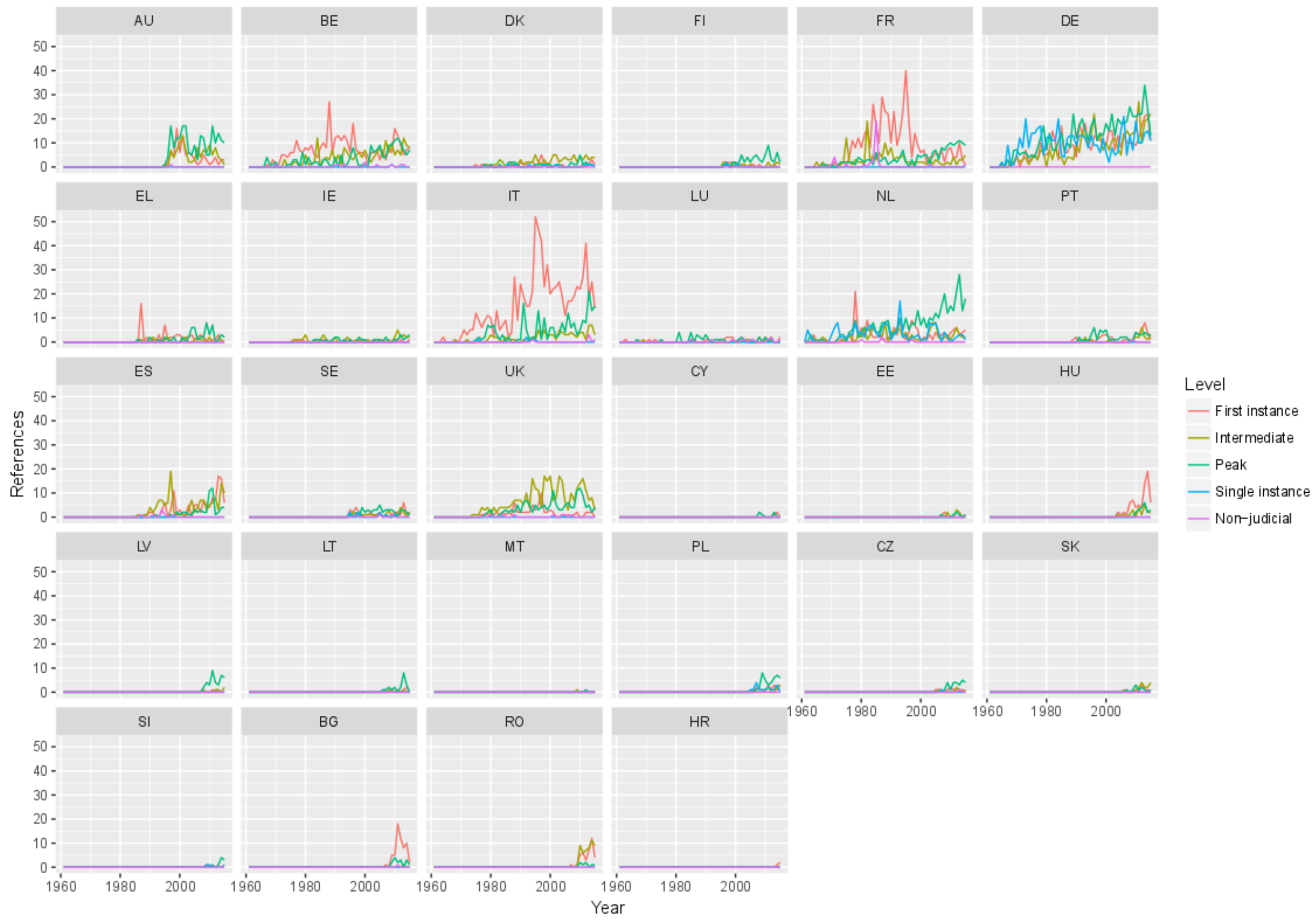

Figure 2. Referral Activity by Court Level and Member State, 1961-2014 
As shown in Figure 2, these patterns hold across most Member States. In Belgium, France and the Netherlands, all founding Member States, lower courts used to dominate Article 267 proceedings. But, as integration progressed, they have been gradually overtaken by peak courts. We also see peak courts leading the pack in Austria, the Czech Republic, Germany (since the late 1980s), Finland, Greece, Ireland, Latvia, Lithuania, Poland, Portugal and Slovenia. Only in Hungary and Bulgaria do first instance courts continue to refer more than the courts above them. Italy would seem to be an outlier given the exceptionally high level of referral activity of its lower judicial bodies. Yet Italy, too, has experienced a catching-up process, with peak and first instance courts virtually tied in 2014. Also confirmed by cross-country analysis is the greater volatility of lower courts' involvement in the preliminary ruling procedure. The more conspicuous blips in Figure 2 mostly result from fleeting surges in preliminary references originating from first instance courts.

These patterns are consistent with both the resource management and the institutionalization hypothesis. The wild random fluctuations that seem to characterize the referral activity of lower courts suggest that use of the preliminary ruling system on these courts is highly "accidental", reflecting the influence of rare, contingent features of legal disputes together with the impact of what may be the more idiosyncratic personal attributes of the judges called on to adjudicate these disputes. Meanwhile, the rise of peak courts gives lie to Karen Alter's court competition hypothesis. Lower court judges, especially at a more advanced stage of integration, do not have stronger structural incentives to use Article 267 than their higher court counterparts. On the contrary, higher resource/workload ratios, greater public scrutiny and the lock-in effect of institutionalization imply that, in a more integrated EU legal order, top courts will have a higher propensity to request preliminary rulings.

Lending further support to the argument that institutionalization has put greater pressure on peak courts to submit references is the behaviour of constitutional courts. The empowerment hypothesis implied that, of all domestic judicial bodies, constitutional courts would have the strongest incentives to resist legal integration. An explanation that dovetails well with the data until, at least, the turn of the millennium, as Figure 3 illustrates. Not only did many constitutional judges go out of their way to place limitation on the domestic application of supremacy and direct effect. ${ }^{53}$ But their referral activity was conspicuous for its absence. Save for the Belgian and Greek constitutional courts, which submitted a couple of references in the 1980s and 1990s, constitutional judges shunned Article 267. Since 2003, however, there appears to have been a change of heart.

\footnotetext{
${ }^{53}$ See Mattias Kumm, The Jurisprudence of Constitutional Conflict: Constitutional Supremacy in Europe before and after the Constitutional Treaty, 11 Eur. LAw J. 262 (2005); Arthur Dyevre, European Integration and National Courts: Defending Sovereignty under Institutional Constraints?, 9 EuR. CONST. LAW REv. EuCONST 139 (2013).
} 


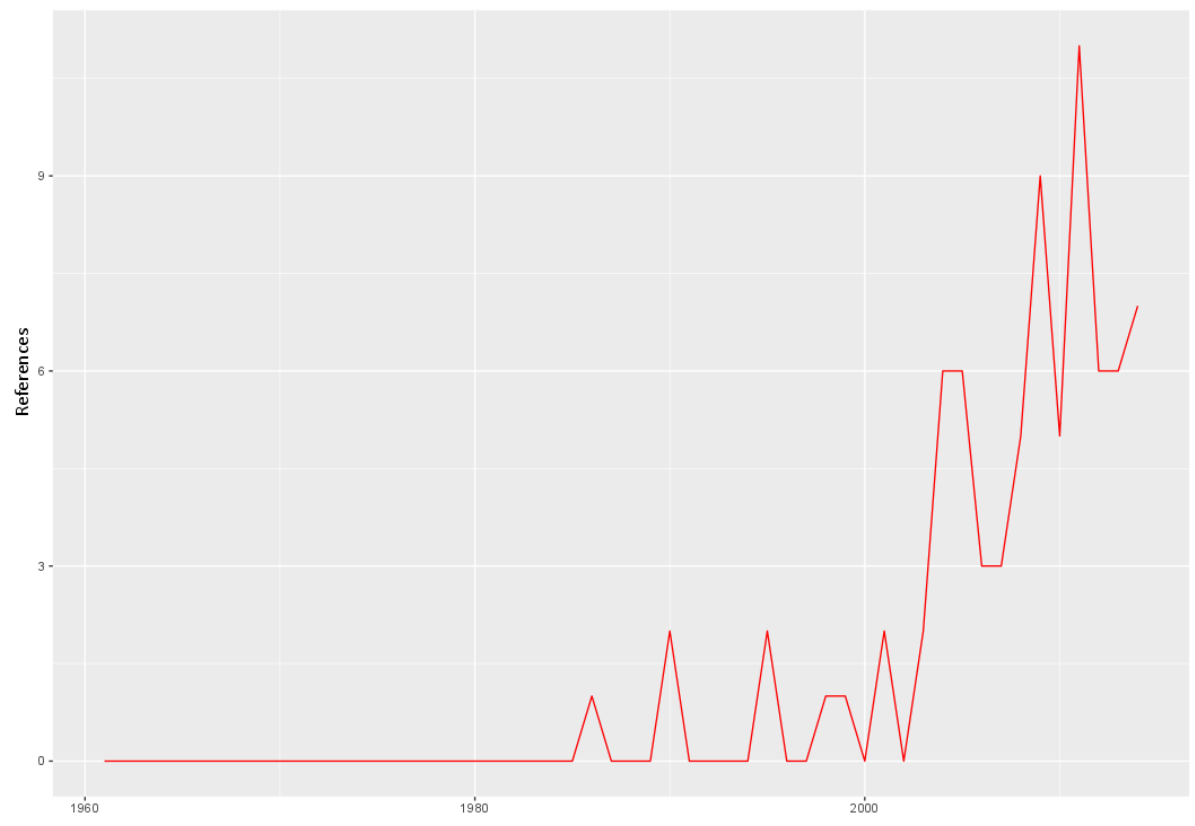

Figure 3. Referral Activity, Constitutional Courts, 1961 - 2014

Although constitutional tribunals continue to account for a small share of preliminary references, the EU has witnessed a host of constitutional premieres in the last 15 years, with the Austrian Verfassungsgerichtshof, the French Conseil Constitutionnel, the German Bundesverfassungsgericht, the Italian Corte costituzionale, the Spanish Tribunal Constitucional, the Lithuanian Konstitucinis Teismas, the Maltese Constitutional Court and the Slovenian Ustavno sodišče all submitting their maiden reference. Predicting that constitutional courts will become enthusiastic users of the preliminary ruling mechanism is certainly premature. Yet this evolution may well be indicative of a greater acceptance of integration.

\subsection{Referral Rates by Subject Matter Jurisdiction}

With all the aforementioned methodological caveats, we now look at how use of Article 267 differs according to the courts' subject matter jurisdiction. On the face of things, it looks as if Figure 4 is suggesting that civil courts make more frequent referrals than administrative ones. But this could simply be the consequence of civil courts processing a larger caseload (alas, reliable data that would permit to control for this explanation is hard to come by). Much more significant is the differential between civil and administrative, on one hand and the three remaining categories (constitutional, other and non-judicial), on the other. 


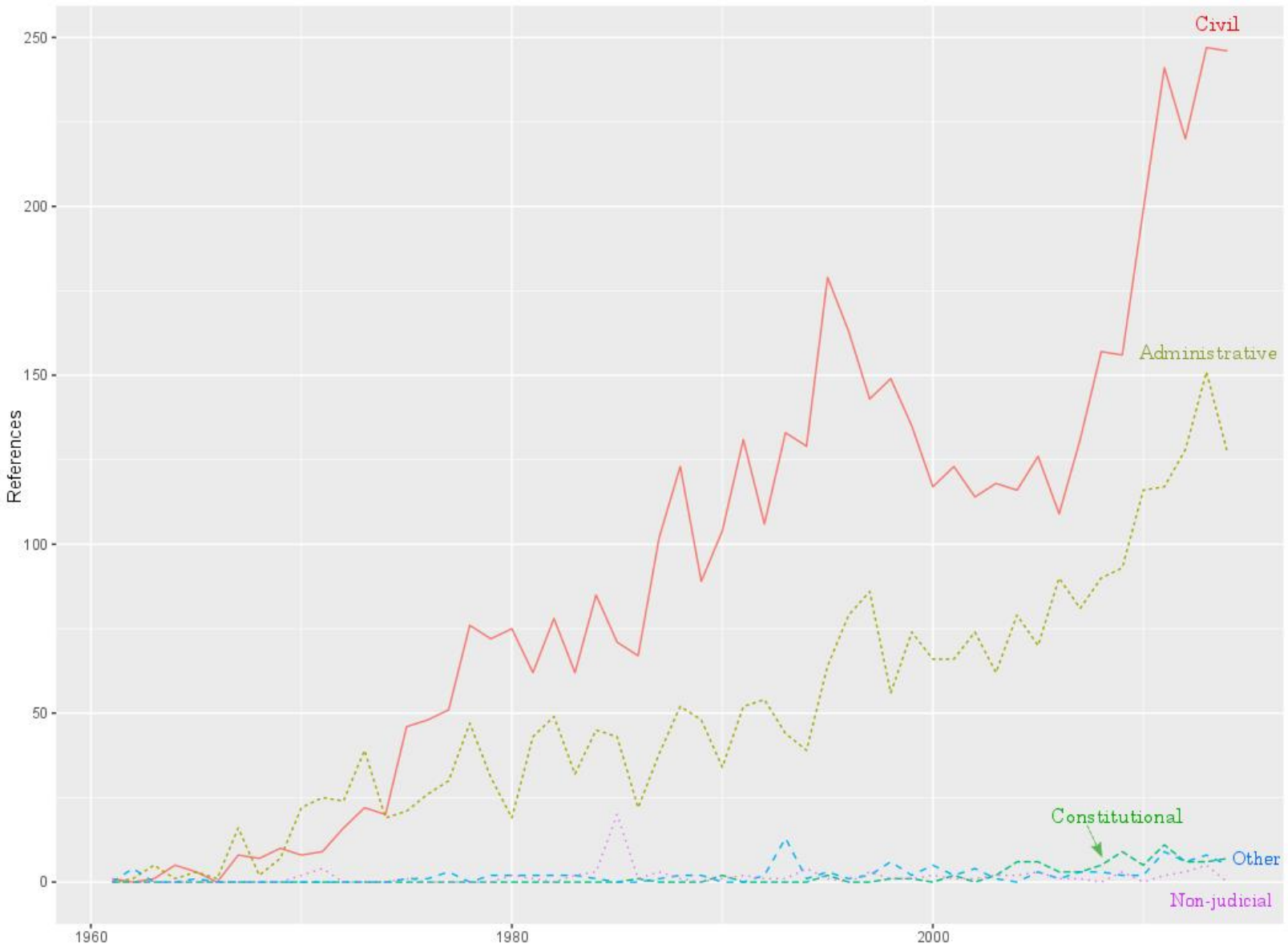

Figure 4, Referral Rates by Subject Matter Jurisdiction, 1961-2014

How does the picture look like across Member States? From the data visualization in Figure 5 we see that civil courts come out on top of the referral league tables in nearly every Member State. Noteworthy are the dynamics observed in founding Member States like France and Italy, where administrative courts initially lagged behind in referral activity but have been catching up on civil ones. The evolution characterizing the referral behaviour of French administrative judges is, plausibly, a consequence of the jurisprudential U-turn taken by the Conseil d'État in the late 1980s, when it put an end to its protracted tug-of-war with the Court of Justice and finally embraced European integration. In other Member States with high referral rates, such as Austria and the Netherlands, civil and administrative courts have been virtually tied since these countries became part of the EU. 


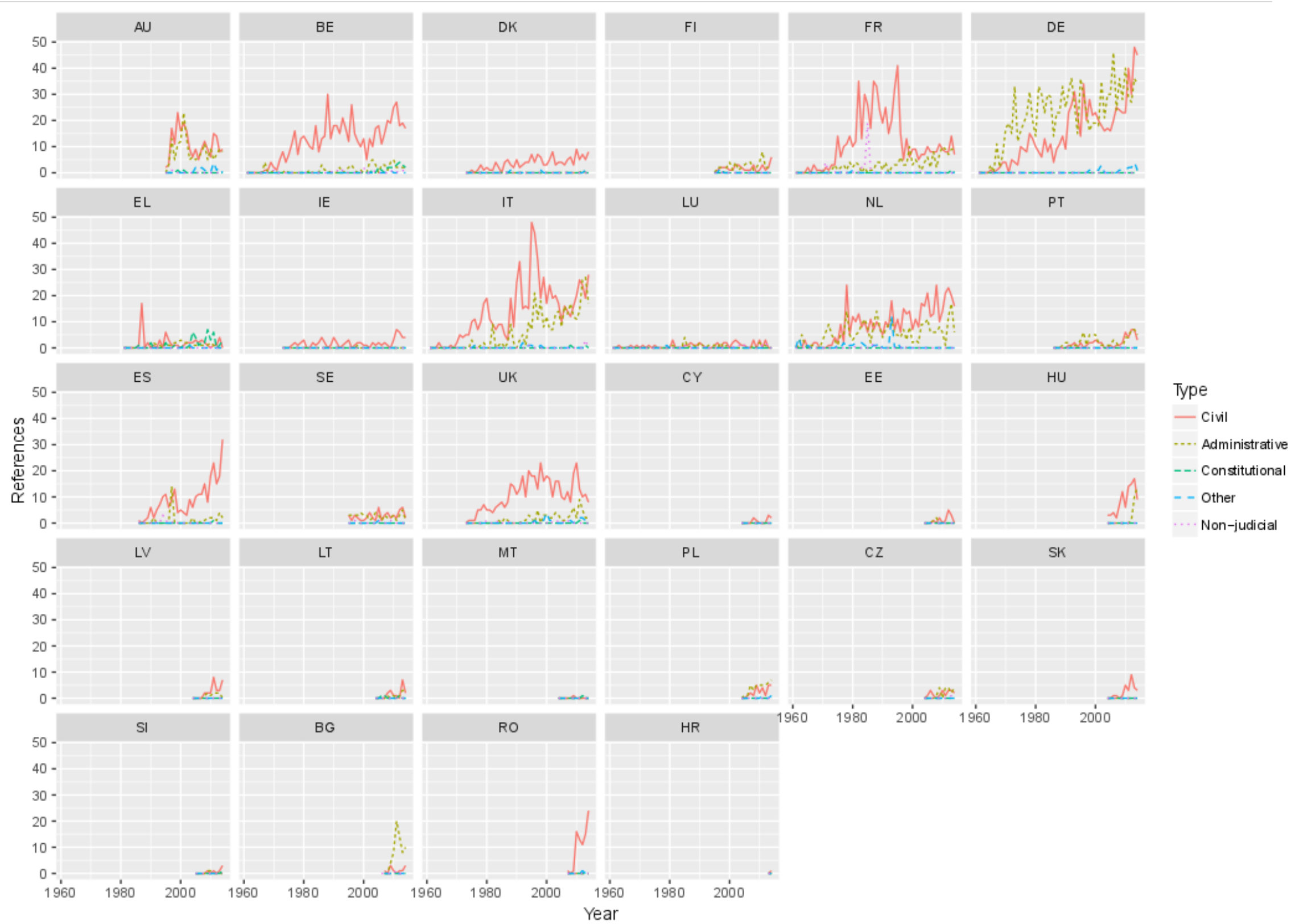

Figure 5. Referral Rates by Subject Matter Jurisdiction and Member State of Origin, 1961-2014 
At first sight, German administrative courts, with referral rates consistently higher than civil courts, look exceptionally active. Yet this is largely an artefact of our operationalization of the category "administrative" courts. Unlike judiciaries in Belgium, the Netherlands, France, Italy, or Sweden — which are essentially structured around two judicial hierarchies, administrative and civil— the German court system comprises five hierarchies - civil, administrative, labour, social and tax — each overseen by its own supreme court. Of these five hierarchies, the one formed by tax courts accounts for a very substantive chunk of the references submitted by German courts. So including tax courts in the administrative category meant it would automatically score high. Administrative law disputes ordinarily pit private persons against the state. And so do tax disputes. However, Germany is arguably an instance where our primary classification comes close to resembling a Procrustean bed.

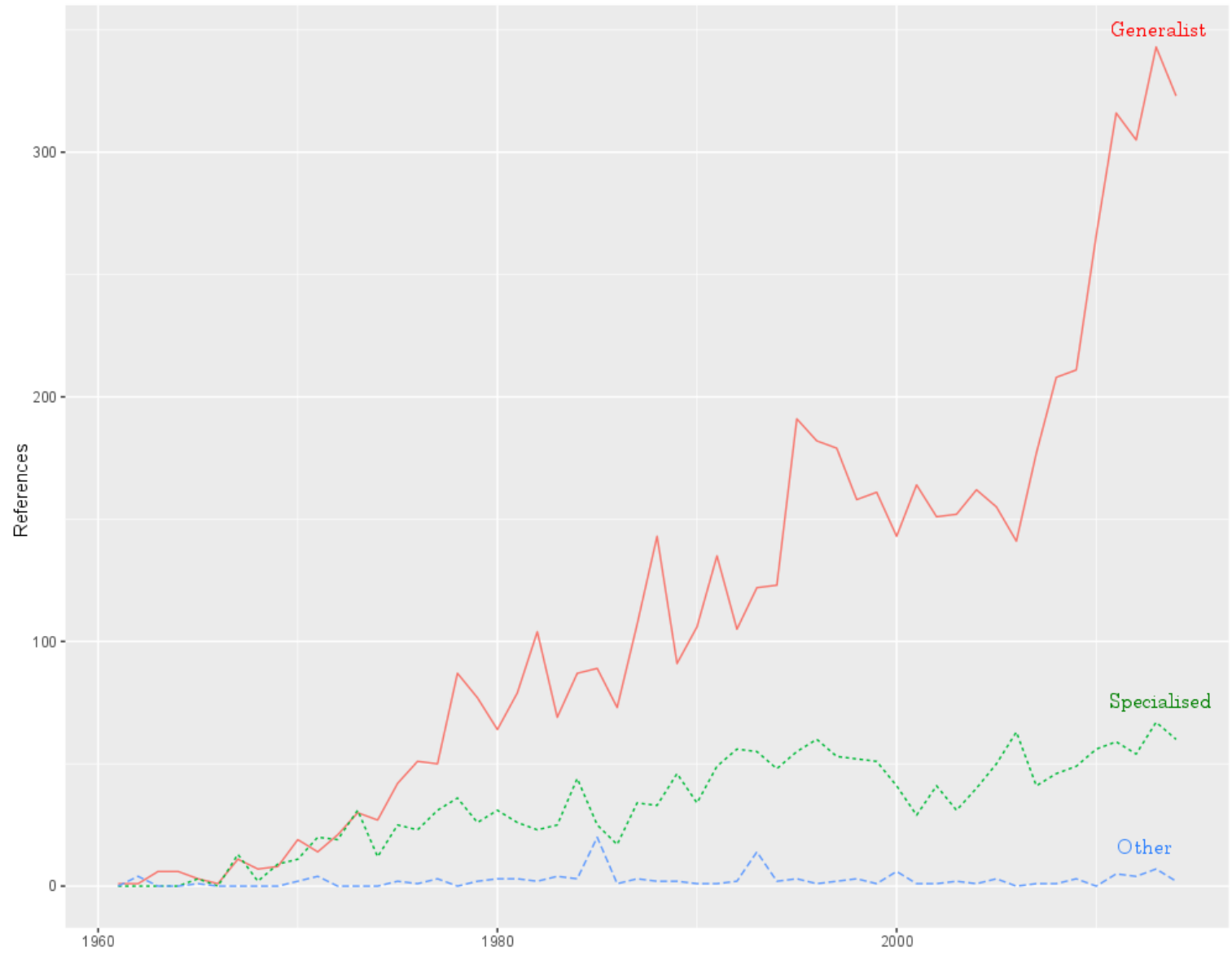

Figure 6. References, Generalist vs Specialised Courts, 1961-2014 
Our alternative classification, distinguishing "generalist" and "specialised" courts, clearly puts the generalist judges ahead (Figure 6). What is more, the gap between the two groups has grown considerably over time. Only in Germany do specialised courts come out on top (Figure 7). But that is because tax courts, this time, are included in this group.

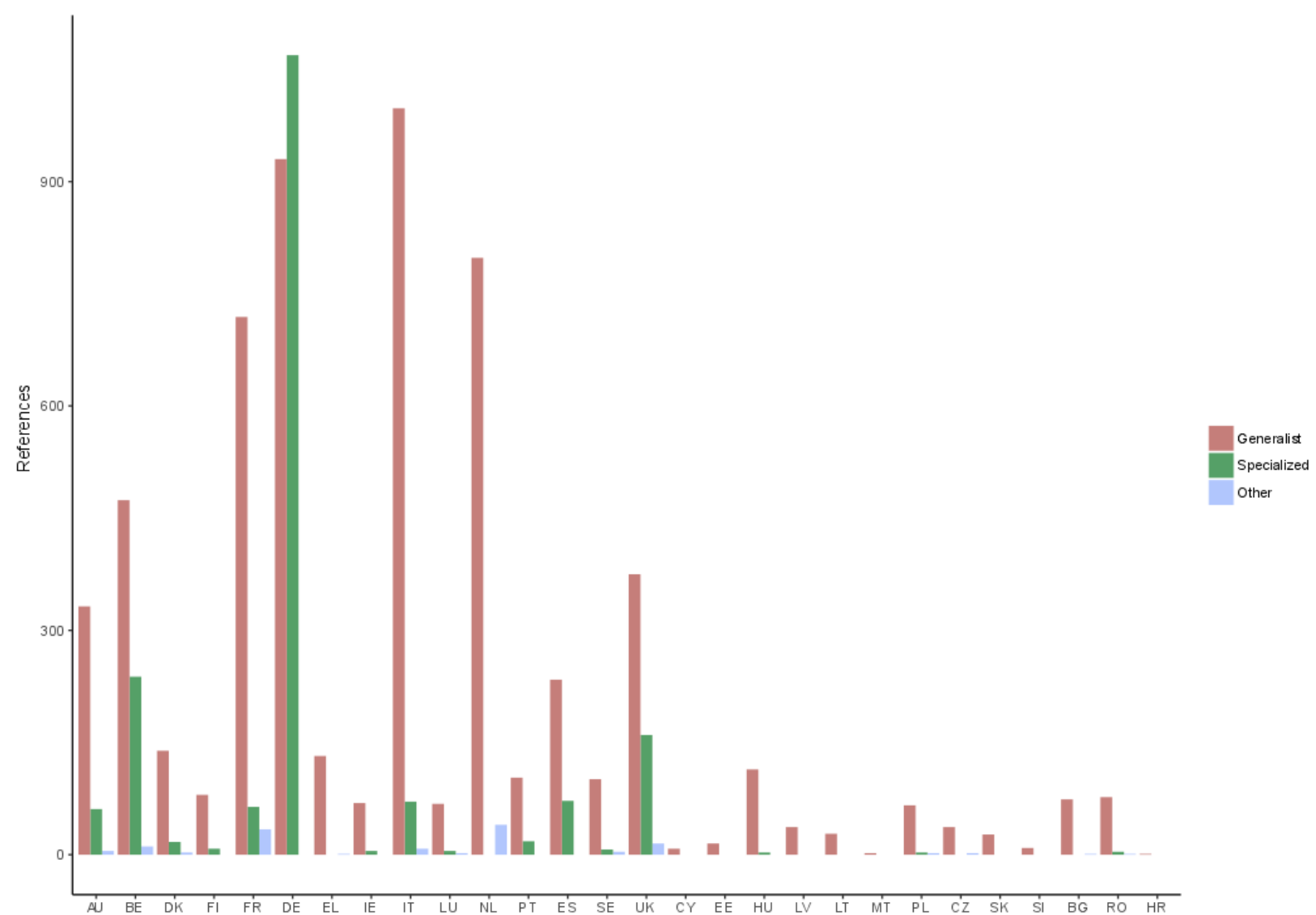

Figure 7. Specialised vs Generalist Courts by Member State, Aggregate 1961-2014

Admittedly, there are many ways to look at the data. Yet we could not find conclusive evidence for the claim that specialised judicial bodies have a stronger propensity to raise preliminary references. Nor could we find much empirical support for the opposite hypothesis. Then civil courts, it is true, tend to submit more than administrative ones. But the difference is not such that we can really say that it generally supports the view that administrative courts are reluctant to pass on questions to the Luxembourg Court or that administrative litigation is less conducive to this form of inter-judicial dialogue. These claims may well have reflected the situation that prevailed in some big Member States prior to the 1990s (e.g. low referral rates for French and Italian administrative courts). But they do not appear to generalize to judicial systems across the territory and lifetime of the European Union. 


\section{Conclusion}

In this paper we tried to contribute to the scholarly debate on the dynamics of the preliminary ruling procedure at both empirical and theoretical level. At theoretical level, we argued that national courts are influenced by the degree of institutional consolidation of EU law as well as by organizational factors, including variations in resource allocation and workload across levels of the judicial hierarchy. Through their effect on the courts' environment and audiences, these factors can induce temporal shifts in referral behaviour. Because top courts enjoy higher resource/workload ratios and face greater public scrutiny, we argued that they should display a higher propensity to request preliminary rulings as the locked-in effect of integration increases the pressure to observe EU law. Empirically then, we showed that first instance courts did pioneer the use of the preliminary ruling procedure. Yet a steady rise in references from peak courts led these to overtake lower courts in the mid-2000s. Peak courts now dominate Article 267 proceedings; and this in most Member States. Our empirical findings debunk the notion that peak courts are referral-shy as outdated. There is little evidence to back the claim that administrative courts are reluctant to file references. Moreover, we showed that the patterns emerging from the data are consistent with our theoretical narrative. Both institutionalization and management constraints have the power to explain shifting patterns of referral activity across courts and time.

We can only encourage further research in this area. We operated on the reasonable assumption that peak courts have more to do less, but researchers may want to collect more fine-grained data on caseload and judicial resources. ${ }^{54}$ Also, our cross-court comparison is based solely on the behaviour of courts that have submitted. New insights may be gained by investigating the courts, particularly at the lower echelons of domestic judicial systems, which have never been involved in Article 267 proceedings.

\footnotetext{
${ }^{54}$ Through CEPEJ, the Council of Europe does claim to collect data on these aspects of national judiciaries. But the data is incomplete and its accuracy questionable.
} 